\title{
Motivation Techniques Used by the Needs of Universities of Highest Education
}

\author{
John E. Goulionis \\ Department of Financial Engineering, University of Aegean \\ 41 Kouduriutou Street, 82100 Chios, Greece \\ E-mail:jgouli@aegean.gr; goulionis25@gmail.com
}

Received: Jan. 20, 2013

Accepted: April 14, $2013 \quad$ Published: May 1, 2013

doi:10.5296/jse.v3i2.3085

URL: http://dx.doi.org/10.5296/jse.v3i2.3085

\begin{abstract}
Motivation of teachers has been a prime concern of University administrations. It is a quality that students, teachers, parents, University administrator, and other members of the community must have if our educational system is to prepare young people adequately for the challenges and demands of the coming century. The main purpose of this study was motivation techniques used by principals of institutions of higher education and their impact on performance of teachers. The major objectives of the study were: i) what are the factors that make teachers "like" teaching as a career or profession, ii) what are the suggestions given by teachers to improve their self motivation, iii) why teachers do not like teaching as a career or profession. The major findings of the study indicate that teachers have reasons in favoring the teaching profession, such as, teaching being noble profession, as an opportunity to contribute towards students' advancement and development, and to fulfill self interest and satisfaction. The previous studies focused on employees other than education from motivational point of view. The present study was designed to remove this deficiency, which might be helpful to suggest some measure to enhance the performance of teachers and students. There are two conditions for motivated teachers. These are: They must feel valued, and they must be resourced. The nature of study was descriptive type. For choosing the sample from this population, random sampling type was used. The sample constituted of 100 males and 100 females. Questionnaires were used as research instruments for collection of data. To analyze the data chi-square as a contingency test and percentage were used. This test is commonly used in analyzing data where two groups or variables are compared.
\end{abstract}

Keywords: Sociology in Education; Statistics in Education; Motivation abilities; Educational measurement 


\section{Introduction.}

Motivation is an important tool that is often under-utilized by heads of universities in today workplace (Ball, 2003). Heads use motivation techniques in the workplace to inspire teachers to work, both individually and in groups, to produce the best results for education in the most efficient and effective manner. It is duty of the heads of universities to carefully identify and address these motivating forces. Motivation for teachers is very significant (Ricks et al. 1995). It is virtually impossible to determine a person's motivation until that person behavior or action an individual performs at each moment in time, the initiation and persistence of an intentional, goal-directed activity (Mifflin, 1995).

In higher educational institutions it is largely the work of the teacher that determines the degree of success or failure in the institutions efforts to achieve its goal of integrating faith and learning (Beard et al. 2007). It's the teacher who gives the institution its credibility and determines its character.

A teacher has the opportunity to influence significantly the student in building a worldview that rests on faith commitment (Reay , 2004 ). Motivation is one of the constructs psychologists have propounded in their quest for understanding the individual (Reay et al., 2009 ), Hoadley, 2008 ). Besides, motivation is the willingness to exert high levels of efforts towards organizational goals conditioned by the efforts and ability to satisfy some individual needs (Greenberg, 1999). To motivate others is one of the most important management tasks (Rowland, 2008). It comprises the abilities to understand what drives people, to communicate, to involve, to challenge, to encourage, to obtain feedback and to provide a just reward (Rowland, 2009). The challenge lies not in the work itself, but in you, the person who creates and manages the work environment (Cook, 1991).

There are many factors that determine people's behavior to motivate them. These are psychological needs, psychological drives, survival, urges, emotions, hurts, impulses, tears, threats, rewards (money, friendship, status, possessions, wishes, intentions, values, mastery, freedom, intrinsic satisfaction, interests, pleasure, dislikes, established habits, goals, ambitions and so on). In any educational institution there is a need for a dynamic leader to emerge. Leadership is the exercise of authority and the making of decision (Dubin, 1951), (Maton, 2009). Educational administration is important wherever two or more people are involved in the execution of some task. The choice of rewards, recognition, reprimands or punishments to motivate personnel help to project the leadership style of the administrator (Khezevich, 1984), ( Schunk and Silver 2002 ).

The University principal should be very concerted about the long-term development needs of teachers. The principal establishing a good working relationship with the teachers and making sure the avenues or effective communication are available and utilized can enhance this. For the university to be effective both the principal and every teacher must realize that the need each other in mutual partnership to plan and implement strategies for the effective leadership of the institution at their respective levels (Maton, 2008).

Teachers in a university have both intrinsic and extrinsic need. A teacher who is intrinsically 
motivated may be observed to undertake a task for its own sake, for the satisfaction it provides or for the feeling of accomplishment and self-actualization. On the other hand, an extrinsically motivated teacher may perform the activity/duty in order to obtain some reward such a salary. Extrinsic motivation plays an important part in people's life. It is very important too strong in influencing a person's behavior. Therefore, the aim of the University organization should be to built on the enhance the intrinsic motivation for teachers to each effectively and at the same time, to supply some extrinsic motivation along the way for University improvement (Kerlinger, 1993).

This paper would focus on effectiveness of higher education. We try to find out the motivational techniques used by heads of Universities to motivate the teachers for their effective performance. This study has not been already conducted in Greece context. Moreover this research elaborated on studying the motivational ability of educational heads. This study had recognized a number of motivational techniques which would much valuable for our teachers. An additive objective is to identify the students' opinions about the views of teachers about the motivational techniques used by their heads.

Lindner (1998) conducted research entitled "Understanding Employee Motivation". The purpose of this study was to describe the importance of certain factors in motivating employees. Specifically, the study sought to describe the ranked importance of the following ten motivating factors: job security, sympathetic help with personal problems, personal loyalty to employees, interesting work, good working conditions, tactful discipline, good ways promotions and growth in the organization, full appreciation of work done, feeling of being in on things. Lope (2004) conducted research entitled "improving the teaching profession through understanding educators self motivation". The major objectives of the study were (a) what are the factors that make teachers "like" teaching as a career or profession (b) what are the suggestions given by teachers to improve their self motivation, (c) why teachers do not like teaching as a career or profession. The major findings of the study indicate that teachers have reasons in favoring the teaching profession, such as, teaching being noble profession, as an opportunity to contribute towards students' advancement and development, and to fulfill self interest and satisfaction. The previous studies focused on employees other than education from motivational point of view. The present study was designed to remove this deficiency, which might be helpful to suggest some measure to enhance the performance of teachers and students. There are two conditions for motivated teachers. These are : (a) They must feel valued, b) They must be resourced.

And we suspect that the first is more important than the second. Perhaps the greatest motivational force for teachers is to feel valued. In order to illustrate some of the factors which are important here we have the following sources of teacher motivation.

> VALUED: The job is worth doing; they are not overworked; pay, promotion are appropriate; they are trusted to take responsibility; there is social esteem; a reasonable measure of public respect.

RESOURCED: Paid appropriately; Adequate equipment and books; A building fit for purpose; they are trained, encouraged, cared for; There is appropriate curriculum guidance. 


\section{Role of motivation in education}

Education must transfer from generation to generation the care of our culture's accumulated body of knowledge. Its importance in educational administration is only beginning to be understood and applied to professional and other adult employees. Teachers motivate learners throw a variety of strategies based on understanding of learner's growth and development patterns, individual ability differences, and of internal and external factors that may arouse and sustain the desire to learn more. These general principles may be adopted to adult motivational strategies of the administrator working with teachers, supervisors, other administrator and other adult workers. Recognition of the motivational value of intrinsic factors such as, desire for achievement or self fulfillment is needed to balance what has been an over reliance, extrinsic motivator factors are external to the person and job satisfaction. Motivation is not the same for everyone. We have different needs, goals and different personalities. Typically, learner motivation is likely to be intrinsic rather than extrinsic. Learner control increases the relevance of the learning and in turn improves learner motivation. Motivated and successful teachers believe that they can inspire their students and that students can learn. According to Carrington and Robinson 2009 , motivation factors are the aspects of a job situation that can, when present, fulfill employees' needs for psychological growth. The six motivation factors are:

1. Achievements: successful or unsuccessful completion of a job; solution or no solution of problems, seeing or not seeing the results of one's work.

2. Recognition: notice in the form of praise or blame for any other person ( a superior or manager, a client, a peer, a professional colleague), personal acknowledgement by management, reward or punishment that is directly related to task accomplishment that was assigned.

3. Work itself: the nature of the tasks to be accomplished in the task. The task themselves might be routine or varied, creative or stultifying, interesting or boring, difficult or easy.

4. Responsibility: presence or absence of autonomy in carrying out job assignments, increase or decrease in authority over others, accountability for task accomplishment.

5. Advancement: actual in status within the organization as a result of performance, promotion, lack of expected promotion, or demotion related to performance.

6. Possibility of growth: changes in the word situation such that advancement is more or less likely and opportunities to learn are increased or decreased.

\section{Research methodology.}

The main purpose of this study was motivation techniques used by principals of institutions of higher education and their impact on performance of teachers. The nature of study was descriptive type.

Population: The population of study comprised the following categories of respondents:(a) All the principals of the public Universities in Greece.(b) All the teachers working in these 
Universities.(c) All the students studying in these Universities.

Data Collection. The researcher visited most of the Universities. Area personally and remaining data were collected with the help of two research assistants.

Data Analysis. Data collected through above mentioned instruments were tabulated, analyzed and interpreted category wise, compare responses of three groups and compare responses of male and female principals, teachers and students. To analyze the data, chi-square as a contingency test and percentage were used. For statistical treatment chi-square was applied using the following formula:

$$
x_{o b s}^{2}=\sum_{\text {cells }} \frac{(\theta-e)^{2}}{e}
$$

\begin{tabular}{|l|l|l|l|l|l|l|}
\hline & \multicolumn{6}{|l|}{ Responses as frequencies } \\
& $\begin{array}{l}\text { Strongly } \\
\text { Agree }\end{array}$ & Agree & Neutral & Disagree & $\begin{array}{l}\text { Strongly } \\
\text { Disagree }\end{array}$ & Totals \\
\hline Group 1 & 10 & 23 & 47 & 21 & 33 & 134 \\
\hline Group 2 & 21 & 28 & 51 & 14 & 16 & 130 \\
\hline Totals & 31 & 51 & 98 & 35 & 49 & 264 \\
\hline Chi-square=11.8 & &
\end{tabular}

where, df: Degree of freedom , $\theta$ : Frequently observed or experimental determined, e: Frequency expected. Chi-square as contingency test was used to compare the frequencies of principals/teachers, teachers/students and principals/students. It was as low used in comparisons of male and female principals, teachers and students responses.

\begin{tabular}{|l|l|l|l|l|}
\hline \multicolumn{5}{|l|}{ Expected frequencies } \\
\hline 15.7 & 25.9 & 49.7 & 17.8 & 24.9 \\
\hline 15.3 & 25.1 & 48.3 & 17.2 & 24.1 \\
\hline
\end{tabular}


Comparing the individual Chi-square value identify the sources of differences. On the basis of the analysis and interpretation of data, the conclusions were drawn.

\section{Results and discussion.}

In this study the data have been interpreted and analysis through Chi-square as a contingency test. The Chi-square is said to be one of the most widely used test for statistical data generated by non-parametric analysis. The Chi-square test is commonly used in analyzing data where two groups or variables are compared. Each of the variables may have two or more categories, which are independent from each other. The data for this comparison is generated from the frequencies in the categories. In the discussion section the data have been interpreted and analysis in three different groups. Compare responses of three groups: a. Principals/teachers b. Teachers/students c. Principals/students. Compare responses of the males and females: a. Male /female principals b. Male/female teachers c. Male/female students. Percentage wise interpretation of the three groups' responses: a. Principals b. Teachers c. Students. The question being addressed is whether the groups differ in their responses from each other. The samples are as follows: Principals: $N=200$; Teachers: $N=1000$; Students: $\mathrm{N}=4000$.

Table 1.

\begin{tabular}{|l|l|l|l|l|l|l|l|l|l|}
\hline \multicolumn{7}{|c|}{ The principal is always constructive and optimistic. } \\
\hline & SA & A & N & D & SD & Comparisons & $X^{2}$ & df & $\mathrm{p}$ \\
\hline Principals & 40 & 20 & 5 & 25 & 10 & $\begin{array}{l}\text { Principals/ } \\
\text { Teachers }\end{array}$ & 86.5 & 4 & $<0.001$ \\
\hline Teachers & 26 & 53 & 6 & 11 & 4 & Teachers/ Students & 148.2 & 4 & $<0.001$ \\
\hline Students & 36 & 42 & 1 & 13 & 8 & Principals/ Students & 61.9 & 4 & $<0.001$ \\
\hline
\end{tabular}

Although some principals hold a strongly positive view, in general they are less positive when compared to their teachers. In many ways, teachers and students hold similar views although the teachers are not quite positive. It is clear that the principals are different in their responses from both other groups, being significantly more holding negative views. The question is difficult to intercept in that two adjectives are used: constructive and optimistic. Perhaps the principals are less optimistic. 
Table 2.

\begin{tabular}{|l|l|l|l|l|l|l|l|l|l|}
\hline & \multicolumn{7}{|c|}{ The principal motives teachers to be more innovative. } \\
\hline & SA & A & N & D & SD & Comparisons & $X^{2}$ & df & $\mathrm{p}$ \\
\hline Principals & 38 & 28 & 11 & 10 & 13 & Principals/ Teachers & 32.7 & 4 & $<0.001$ \\
\hline Teachers & 30 & 49 & 5 & 9 & 7 & Teachers/ Students & 136.0 & 4 & $<0.001$ \\
\hline Students & 35 & 38 & 2 & 21 & 4 & Principals/ Students & 108.1 & 4 & $<0.001$ \\
\hline
\end{tabular}

All groups are positive but the principals are less confident and teachers are most confident. Perhaps the principals are most sure that they are achieving what they want to achieve while the teachers are more aware of the motivating effects. It is possible that teachers think they are more innovative than they are, see ( Brophy and Good, 2007 ).

Table 3.

\begin{tabular}{|l|l|l|l|l|l|l|l|l|l|}
\hline & \multicolumn{7}{|c|}{ The principal appreciates his teachers' work openly } \\
\hline & SA & A & N & D & SD & Comparisons & $X^{2}$ & df & p \\
\hline Principals & 2 & 10 & 6 & 44 & 38 & Principals/ Teachers & 232.4 & 3 & $<0.001$ \\
\hline Teachers & 18 & 50 & 6 & 16 & 10 & Teachers/ Students & 285.3 & 4 & $<0.001$ \\
\hline Students & 41 & 32 & 2 & 21 & 4 & Principals/ Students & 536.9 & 3 & $<0.001$ \\
\hline
\end{tabular}

There are very large differences in the views of the three groups, with the principals very much less positive than the others. The students hold much more positive views than the other groups. Perhaps, principal may unintentionally appreciate their teachers' work while teachers give much importance to it. We have similar results, (Bracey, 2006). 
Table 4.

\begin{tabular}{|l|l|l|l|l|l|l|l|l|l|}
\hline \multicolumn{7}{|c|}{ The principal is stiff in his dealings. } \\
\hline & SA & A & N & D & SD & Comparisons & $X^{2}$ & df & $\mathrm{p}$ \\
\hline Principals & 20 & 32 & 3 & 28 & 17 & Principals/ Teachers & 125.5 & 4 & $<0.001$ \\
\hline Teachers & 9 & 10 & 3 & 24 & 54 & Teachers/ Students & 49.1 & 4 & $<0.001$ \\
\hline Students & 8 & 9 & 2 & 36 & 45 & Principals/ Students & 185.2 & 4 & $<0.001$ \\
\hline
\end{tabular}

Principals have positive views while teachers and students have negative views. Teachers are more negative than the students. It is clear that principals are different in their responses from both other groups. The teachers and students do not consider that the principals are treating them stiffly. However, the principals think they stiff in their dealings. There are similar results, in the paper of (Carrington and Robinson, 2009).

Table 5.

\begin{tabular}{|l|l|l|l|l|l|l|l|l|l|}
\hline \multicolumn{7}{|c|}{ The principal acknowledges the teachers' achievements } \\
\hline & SA & A & N & D & SD & Comparisons & $X^{2}$ & df & $\mathrm{p}$ \\
\hline Principals & 25 & 43 & 2 & 15 & 15 & Principals/ Teachers & 11.2 & 3 & $<0.05$ \\
\hline Teachers & 35 & 41 & 4 & 11 & 9 & Teachers/ Students & 33.4 & 3 & $<0.001$ \\
\hline Students & 36 & 37 & 3 & 9 & 15 & Principals/ Students & 13.2 & 3 & $<0.01$ \\
\hline
\end{tabular}

All the groups are more positive in views but teachers are most confident as compared to principals. It may reflect that the principals acknowledge the teachers achievements. There are similar theoretical results, in the paper of (Hoy and Miskel, 2005 ). 
Table 6.

\begin{tabular}{|l|l|l|l|l|l|l|l|l|l|}
\hline \multicolumn{7}{|c|}{ The principal encourages hard working teachers. } \\
\hline & SA & A & N & D & SD & Comparisons & $X^{2}$ & df & $\mathrm{p}$ \\
\hline Principals & 30 & 38 & 7 & 17 & 8 & $\begin{array}{l}\text { Principals/ } \\
\text { Teachers }\end{array}$ & 12.7 & 4 & $<0.05$ \\
\hline Teachers & 32 & 43 & 6 & 9 & 10 & Teachers/ Students & 90.4 & 4 & $<0.001$ \\
\hline Students & 34 & 37 & 2 & 15 & 12 & Principals/ Students & 29.7 & 4 & $<0.001$ \\
\hline
\end{tabular}

All the groups show more positive attitudes. This shows that principals encourage hard working teachers. For theoretical validity Lester and Bishop 2000.

Table 7.

\begin{tabular}{|l|l|l|l|l|l|l|l|l|l|}
\hline \multicolumn{7}{|c|}{ The principal gives his teachers an appropriate workload. } \\
\hline & S & A & N & D & SD & Comparisons & $X^{2}$ & df & $p$ \\
\hline Principals & 39 & 28 & 3 & 25 & 5 & Principals/ Teachers & 51.7 & 4 & $<0.001$ \\
\hline Teachers & 37 & 43 & 5 & 9 & 6 & Teachers/ Students & 63.6 & 4 & $<0.001$ \\
\hline Students & 33 & 37 & 3 & 16 & 11 & Principals/Students & 21.1 & 4 & $<0.001$ \\
\hline
\end{tabular}

Although, all groups have highly positive views but comparatively teachers have the most positive views. All groups verifying that principals assign appropriate workload to their teachers. 
Table 8.

\begin{tabular}{|l|l|l|l|l|l|l|l|l|l|}
\hline \multicolumn{7}{|c|}{ The principal creates a professional competition among teachers. } \\
\hline & SA & A & N & D & SD & Comparisons & $X^{2}$ & df & $p$ \\
\hline Principals & 8 & 24 & 5 & 43 & 20 & $\begin{array}{l}\text { Principals/ } \\
\text { Teachers }\end{array}$ & 193.8 & 4 & $<0.001$ \\
\hline Teachers & 40 & 28 & 4 & 12 & 8 & Teachers/Students & 1177.6 & 4 & $<0.001$ \\
\hline Students & 10 & 14 & 2 & 33 & 41 & Principals/Students & 46.4 & 4 & $<0.001$ \\
\hline
\end{tabular}

The views of three groups show very large differences and all groups a high degree of polarization of views. Both principals and students show negative attitudes but principals' views are more negative than the students. In general, teachers consider that principals create professional competition among them but the majority of the principals do not think that they create professional competition among teachers. This needs further exploration see Reay, (2004).

Table 9.

\begin{tabular}{|l|l|l|l|l|l|l|l|l|l|}
\hline \multicolumn{7}{|c|}{ The principal acts like role model for teachers. } \\
\hline & SA & A & N & D & SD & Comparisons & $X^{2}$ & df & $\mathrm{p}$ \\
\hline Principals & 28 & 44 & 7 & 15 & 6 & $\begin{array}{l}\text { Principals/ } \\
\text { Teachers }\end{array}$ & 25.2 & 4 & $<0.001$ \\
\hline Teachers & 28 & 52 & 3 & 7 & 10 & Teachers/ Students & 171 & 4 & $<0.001$ \\
\hline Students & 41 & 32 & 2 & 16 & 9 & Principals/ Students & 39.7 & 4 & $<0.001$ \\
\hline
\end{tabular}

Teachers are the most confident among all the groups. Perhaps teachers are most sure that principals act like role model for them. 
Table 10.

\begin{tabular}{|l|l|l|l|l|l|l|l|l|l|}
\hline \multicolumn{7}{|c|}{ The principal criticizes the teachers in a constructive way. } \\
\hline & SA & A & N & D & SD & Comparisons & $X^{2}$ & df & $\mathrm{p}$ \\
\hline $\begin{array}{l}\text { Principal } \\
\text { s }\end{array}$ & 29 & 48 & 6 & 7 & 10 & Principals/ Teachers & 18.8 & 4 & $<0.001$ \\
\hline Teachers & 42 & 36 & 3 & 11 & 8 & Teachers/Students & 22.1 & 4 & $<0.001$ \\
\hline Students & 35 & 38 & 2 & 15 & 10 & Principals/Students & 22.2 & 4 & $<0.001$ \\
\hline
\end{tabular}

All groups hold quite strong positive views. Both principals and teachers are similar in their views while students' views are slight less positive. It is clear that the principals criticize the teachers in a constructive way, see Rolstand (2005).

Table 11.

\begin{tabular}{|l|l|l|l|l|l|l|l|l|l|}
\hline \multicolumn{7}{|c|}{ The principal expresses his opinions forcefully. } \\
\hline & SA & A & N & D & SD & Comparisons & $X^{2}$ & df & $p$ \\
\hline Principals & 15 & 11 & 7 & 40 & 27 & Principals/ Teachers & 140.3 & 4 & $<0.001$ \\
\hline Teachers & 31 & 38 & 5 & 17 & 9 & Teachers/ Students & 820.5 & 4 & $<0.001$ \\
\hline Students & 7 & 18 & 4 & 32 & 39 & Principals/ Students & 39.5 & 4 & $<0.001$ \\
\hline
\end{tabular}

There is a significant difference among three groups. Teachers' views are very much less negative than the others. The students' hold more polarized than the principals. Perhaps, teachers think that principals express their opinions forcefully. 
Table 12.

\begin{tabular}{|l|l|l|l|l|l|l|l|l|l|}
\hline \multicolumn{7}{|c|}{ The principal applies leave rules equally and fairly. } \\
\hline & SA & A & N & D & SD & Comparisons & $X^{2}$ & df & $p$ \\
\hline Principals & 24 & 43 & 5 & 16 & 12 & Principals/ Teachers & 17.7 & 3 & $<0.001$ \\
\hline Teachers & 38 & 42 & 1 & 11 & 8 & Teachers/ Students & 29.6 & 3 & $<0.001$ \\
\hline Students & 43 & 36 & 1 & 15 & 5 & Principals/ Students & 42.3 & 3 & $<0.001$ \\
\hline
\end{tabular}

Almost all groups hold positive views but the principals' views are less positive as compare to others. Teachers and students hold views. It is clear that some principals apply leave rules Fairly and equally. Also see Rossel (2002).

Table 13.

\begin{tabular}{|l|l|l|l|l|l|l|l|l|l|}
\hline \multicolumn{7}{|c|}{ The principal develops habits of self-study among teachers. } \\
\hline & SA & A & N & D & SD & Comparisons & X2 & Df & $\mathrm{p}$ \\
\hline Principals & 20 & 16 & 6 & 24 & 34 & Principals/ Teachers & 134.4 & 4 & $<0.001$ \\
\hline Teachers & 52 & 24 & 3 & 11 & 10 & Teachers/ Students & 95.4 & 4 & $<0.001$ \\
\hline Students & 35 & 32 & 3 & 18 & 12 & Principals/ Students & 104.2 & 4 & $<0.001$ \\
\hline
\end{tabular}

A significant difference occurs the views of three groups. The principals' views are very much less positives than the others. The teachers hold more polarized views than the students. Perhaps, principal develops habits of self-study among teachers and teachers develop self-study among students. Also see Rossel and Baker (1996). 
Table 14.

\begin{tabular}{|l|l|l|l|l|l|l|l|l|l|}
\hline \multicolumn{7}{|c|}{ The principal provides an ambience environment to the teachers. } \\
\hline & SA & A & N & D & SD & Comparisons & X2 & Df & $p$ \\
\hline Principals & 28 & 23 & 6 & 25 & 18 & Principals/ Teachers & 10.9 & 4 & $<0.05$ \\
\hline Teachers & 38 & 22 & 8 & 21 & 11 & Teachers/ Students & 92.7 & 4 & $<0.001$ \\
\hline Students & 41 & 32 & 4 & 16 & 7 & Principals/ Students & 54.3 & 4 & $<0.001$ \\
\hline
\end{tabular}

All groups hold similar positive views. But the principals have less positive views as compare to teachers and students. It is possible that teachers think that they are provided more ambience environments that it actual exist by the principals. Also see Rossel and Baker (1996).

Table 15.

\begin{tabular}{|l|l|l|l|l|l|l|l|l|l|}
\hline \multicolumn{7}{|c|}{ The principal indiscriminately allows to enjoy fringe benefits. } \\
\hline & SA & A & N & D & SD & Comparisons & $X^{2}$ & df & $\mathrm{p}$ \\
\hline $\begin{array}{l}\text { Principa } \\
\text { ls }\end{array}$ & 12 & 23 & 4 & 20 & 41 & Principals/ Teachers & 207 & 3 & $<0.001$ \\
\hline Teachers & 48 & 29 & 2 & 14 & 7 & Teachers/ Students & 23.8 & 3 & $<0.001$ \\
\hline Students & 41 & 34 & 2 & 10 & 13 & Principals/Students & 218.2 & 3 & $<0.001$ \\
\hline
\end{tabular}

Both teachers and students hold similar views, but teachers are more positive than students.

It is clear that principals are different in their responses from both other groups, being significantly more holding negative views. 
Table 16.

\begin{tabular}{|l|l|l|l|l|l|l|l|l|l|}
\hline \multicolumn{7}{|c|}{} & \multicolumn{7}{|c|}{ The principal provides job security to his teachers. } \\
\hline & SA & A & N & D & SD & Comparisons & $X^{2}$ & df & $p$ \\
\hline Principals & 16 & 20 & 7 & 27 & 30 & Principals/ Teachers & 88.3 & 4 & $<0.001$ \\
\hline Teachers & 36 & 31 & 5 & 18 & 10 & Teachers/ Students & 663.5 & 4 & $<0.001$ \\
\hline Students & 11 & 15 & 3 & 35 & 36 & Principals/ Students & 21.1 & 4 & $<0.001$ \\
\hline
\end{tabular}

There is a significant difference in the views of three groups, with the teachers very much less negative than the others. The students hold more negatively polarized views than the principals. Perhaps, principals do not provide job security to their teachers.

Table 17.

\begin{tabular}{|l|l|l|l|l|l|l|l|l|l|}
\hline \multicolumn{7}{|c|}{} & \multicolumn{7}{|l|}{ The principal consult his teachers to take in decisious-making. } \\
\hline & SA & A & N & D & SD & Comparisons & $X^{2}$ & df & $\mathrm{p}$ \\
\hline Principals & 9 & 15 & 7 & 36 & 33 & Principals/ Teachers & 137.4 & 4 & $<0.001$ \\
\hline Teachers & 43 & 23 & 4 & 18 & 12 & Teachers/ Students & 27.7 & 4 & $<0.001$ \\
\hline Students & 43 & 29 & 3 & 17 & 8 & Principals/ Students & 255.5 & 4 & $<0.001$ \\
\hline
\end{tabular}

There are considerable differences in the views of three groups, with the principals very much less positives than the others. All the groups show marked polarization of views. Teachers fell they are consulted but the principals are not nearly as sure of this. 
Table 18.

\begin{tabular}{|l|l|l|l|l|l|l|l|l|l|}
\hline \multicolumn{7}{|c|}{ The principal provides ample chances for professional growth } \\
\hline & SA & A & N & D & SD & Comparisons & X2 & Df & $p$ \\
\hline Principals & 6 & 27 & 5 & 33 & 29 & Principals/ Teachers & 243.4 & 4 & $<0.001$ \\
\hline Teachers & 54 & 27 & 3 & 10 & 6 & Teachers/ Students & 91.7 & 4 & $<0.001$ \\
\hline Students & 41 & 40 & 2 & 7 & 10 & Principals/ Students & 274.2 & 4 & $<0.001$ \\
\hline
\end{tabular}

There are note worthy differences in the views of three groups, with the principals very much less positive than the others. Teachers and students views are similar. It occurs because some principals provide ample chances for professional growth. Also see Tarter (2004).

Table 19.

\begin{tabular}{|l|l|l|l|l|l|l|l|l|l|}
\hline & \multicolumn{7}{|c|}{ The principal is never reluctant to allow the teachers freedom of action. } \\
\hline & SA & A & N & D & SD & Comparisons & X2 & Df & $p$ \\
\hline Principals & 11 & 30 & 5 & 33 & 29 & Principals/ Teachers & 228.5 & 4 & $<0.001$ \\
\hline Teachers & 35 & 48 & 2 & 9 & 6 & Teachers/ Students & 96.8 & 4 & $<0.001$ \\
\hline Students & 41 & 32 & 3 & 13 & 11 & Principals/ Students & 192.3 & 4 & $<0.001$ \\
\hline
\end{tabular}

There are major differences in the views of three groups, with the principals a large extent less positive than the others. All the groups hold polarized views this is difficult question because of the use of the world 'never'. It is negative and very strong. Assuming that the groups answered the question correctly, teachers seem to see themselves as having greater freedom than the principals. 
Table 20.

\begin{tabular}{|l|l|l|l|l|l|l|l|l|l|}
\hline & \multicolumn{7}{|c|}{$\begin{array}{l}\text { The principal places staff members on jobs in which their individual abilities } \\
\text { are most likely to be fully utilized. }\end{array}$} \\
\hline & SA & A & N & D & SD & Comparisons & $X^{2}$ & df & $p$ \\
\hline Principals & 47 & 24 & 2 & 15 & 12 & Principals/ Teachers & 38.5 & 3 & $<0.001$ \\
\hline Teachers & 31 & 48 & 2 & 16 & 9 & Teachers/ Students & 1373.2 & 3 & $<0.001$ \\
\hline Students & 8 & 10 & 3 & 36 & 43 & Principals/ Students & 369.9 & 3 & $<0.001$ \\
\hline
\end{tabular}

There is a clear difference in the views of three groups. Teachers hold more polarized views than the principals and students hold very much less positive as compare to the teachers. It is due to principals' placement staff members on jobs according to their teachers' ability and interest while students have slight awareness about teachers' ability. The above results are according to the theoretical results of Rossel and Baker (1996).

Table 21.

\begin{tabular}{|l|l|l|l|l|l|l|l|l|l|}
\hline \multicolumn{7}{|c|}{ The principal establishes a good relationship with his teachers. } \\
\hline & SA & A & N & D & SD & Comparisons & $X^{2}$ & df & $\mathrm{p}$ \\
\hline $\begin{array}{l}\text { Principa } \\
\text { ls }\end{array}$ & 23 & 38 & 3 & 22 & 14 & Principals/ Teachers & 14.7 & 3 & $<0.001$ \\
\hline Teachers & 34 & 39 & 2 & 16 & 9 & Teachers/ Students & 3.1 & 3 & n.s \\
\hline Students & 36 & 40 & 2 & 14 & 8 & Principals/ Students & 25.3 & 3 & $<0.001$ \\
\hline
\end{tabular}

All groups hold positive views but the principals are less confident compared to teachers and students. Perhaps, principals are less sure that they are achieving what they want to achieve while teachers are more aware of the motivating effects. It is possible that teachers think that principals establish a good relationship with them. The above results are according to the theoretical results of Rossel (2002). 
Table 22.

\begin{tabular}{|l|l|l|l|l|l|l|l|l|l|}
\hline & \multicolumn{7}{|c|}{ The principal assigns the examination duties among his teachers justly. } \\
\hline & SA & A & N & D & SD & Comparisons & $X^{2}$ & df & $\mathrm{p}$ \\
\hline Principals & 12 & 13 & 7 & 41 & 27 & Principals/ Teachers & 32.1 & 4 & $<0.001$ \\
\hline Teachers & 13 & 15 & 3 & 25 & 44 & Teachers/ Students & 916.4 & 4 & $<0.001$ \\
\hline Students & 45 & 31 & 2 & 12 & 10 & Principals/ Students & 258.4 & 4 & $<0.001$ \\
\hline
\end{tabular}

Both principals and teachers are negative in their views. Among all the groups only students have positive views. This means that students are ignorant of principals polices that is why they are positive. Overall examination duties are not assigned to teachers justly. The above results are according to the theoretical results of Tarter (2004)

Table 23.

\begin{tabular}{|l|l|l|l|l|l|l|l|l|l|}
\hline \multicolumn{1}{|l|}{} \\
The principal awards teachers with financial incentive for extra academic \\
work. \\
\hline
\end{tabular}

There are considerable differences in the views of three groups. Teachers hold more positive views while others hold negative views. The students hold more negative views than the principals. Teachers' attitudes show that they are awarded with financial incentives. The above results are according to the theoretical results of Rossel (2002). 
Table 24.

\begin{tabular}{|l|l|l|l|l|l|l|l|l|l|}
\hline & \multicolumn{9}{|c|}{ The principal assists and leads his teachers to gain achievable targets. } \\
\hline & SA & A & N & D & SD & Comparisons & $X^{2}$ & df & $\mathrm{p}$ \\
\hline Principals & 32 & 45 & 4 & 11 & 8 & Principals/ Teachers & 30.0 & 4 & $<0.001$ \\
\hline Teachers & 44 & 25 & 5 & 16 & 10 & Teachers/ Students & 160.4 & 4 & $<0.001$ \\
\hline Students & 28 & 43 & 2 & 18 & 9 & Principals/ Students & 9.9 & 4 & n.s \\
\hline
\end{tabular}

The views of all the respondents are positive. Teachers are less positive than other groups. Their attitude shows that principals assist and lead teachers to achieve targets, according the theoretical results of Rolstand et al. (2005).

Table 25.

\begin{tabular}{|l|l|l|l|l|l|l|l|l|l|}
\hline & \multicolumn{9}{|c|}{ The principal ensures evaluation of teachers 'performance regularly. } \\
\hline & SA & A & N & D & SD & Comparisons & $X^{2}$ & df & $\mathrm{p}$ \\
\hline Principals & 20 & 15 & 4 & 35 & 26 & $\begin{array}{l}\text { Principals/ } \\
\text { Teachers }\end{array}$ & 147.4 & 3 & $<0.001$ \\
\hline Teachers & 46 & 32 & 2 & 11 & 9 & Teachers/ Students & 1015.2 & 4 & $<0.001$ \\
\hline Students & 11 & 16 & 3 & 32 & 38 & Principals/ Students & 22.9 & 3 & $<0.001$ \\
\hline
\end{tabular}

There are considerable differences in the views of three groups. The teachers are markedly more in agreement with the statement while all the groups show considerable polarization of view. Perhaps this reflects that the teachers think they are somewhat over-evaluated while the principals think they have it about right. The degree of polarization seems to suggest different practices in different schools, according the theoretical results of Beard et al. (2007). 
Table 26.

\begin{tabular}{|l|l|l|l|l|l|l|l|l|l|}
\hline & \multicolumn{9}{|c|}{ The principal reposes his teachers for achieving institution goals. } \\
\hline & SA & A & N & D & SD & Comparisons & $X^{2}$ & df & $p$ \\
\hline Principals & 30 & 37 & 6 & 10 & 17 & Principals/ Teachers & 17.6 & 3 & $<0.001$ \\
\hline Teachers & 43 & 31 & 2 & 14 & 10 & Teachers/ Students & 1091.3 & 3 & $<0.001$ \\
\hline Students & 13 & 8 & 3 & 36 & 40 & Principals/ Students & 263.2 & 3 & $<0.001$ \\
\hline
\end{tabular}

The samples are so; chi-square values are very large there are large differences in the views of three groups respondents. Both principals and teachers are positive, while students are negative in their views. It shows that principals repose their teachers for achieving instructions goals, according the theoretical results of Bracey, 2006.

\section{Conclusion}

Following conclusions were drawn in the light of finding of the study.

Majority of the principals hold that they are constructive as well as optimistic, appreciate intentionally and a good deal of principals are very stiff in their dealing. Majority of teachers and students agree that their principals provide personal loyalty to them. Some principals appreciate the teacher to develop sense of humor. They also care teacher's ego, establish good relationship with them and assign them appropriate workload according to their choice and interest. Majority of the principals believe in fair play in all academic matter and criticize the teachers in constructive way and encourage hard worker teachers. Majority of principals give no importance to professional competition among teachers, instructional technology and job security. A good deal of principals believes in favoritism and assign examination duties to their favorite teachers. Majority of teachers view that techniques used by heads which do not increase the performance or have negatively influence are favoritism through improper application of leave rules inequality in assignment of examination duties dicrimination in fringe benefits, absence of job security, lack of feedback on academic matters and irregual evaluation of the teacher.

\section{References}

Ball, S. J. (2003). The teacher's soul and the terrors of performativity. Journal of Education Policy, 18(2), 215-28. http://dx.doi.org/10.1080/0268093022000043065

Beard, C., S. Clegg, \& K. Smith. (2007). Acknowledging the affective in higher education. British Educational Research Journal, 35(2), 235-52. http://dx.doi.org/10.1080/01411920701208415 
Bracey, G. W. (2006). Reading educational research: How to avoid getting statistically snookered. Portsmouth, NH: Heinemann.

Brophy, J., \& Good, T.L. (2007). Looking in classrooms (10th ed.). New York: Allyn and Bacon. California Education Code $§ 300-340$ (1998)

Carrington, V., \& M. Robinson, eds. (2009). Digital literacies: Social learning and classroom practice. London: Sage.

Cook, M. (1991). 10- Minute guide to motivating people. Alpha Book Publishers, NY, USA.

Dubin, R. (1951). The Sociology of organization with reading and cases. Prentice- Hall. New Jersey, USA.

Greenberg, j. (1999). Managing Behavior in Organizational Second edition Prentice-Hall. New Jersey, USA.

Hoy, W. K., \& Miskel, C. G. (2005). Educational administration: Theory, research, and practice. New York: McGraw-Hill.

Kerlinger, F.N. (1993). Foundations of Behavioral Research, Holt Rinehard and Winston New

Khezevich S. J. (1984). Administration of public education, fourth edition. Harper and Row Publishers, New York, USA.

Lindner, J.R. (1998). Understanding Employee Motivation. Journal of extension research and extension Associate, 36(3), 9-16. Ohio State University.

Lester, P., \& Bishop, L.K. (2000). Handbook of Tests and Measurement in Education and The Social Sciences. Lanham, Maryland: The Scarecrow Press.

Lope, Z.A. (2004). Improving the teaching profession through understanding educators Self Motivation. Pakistan Journal of Psychological Research, 19, 25-35.

Hoadley, U. (2008). Social class and pedagogy: A model for the investigation of pedagogic variation. British Journal of Sociology of Education, 29(1), 63-78. http://dx.doi.org/10.1080/01425690701742861

Maton, K. (2008). Grammars of sociology. Paper presented at the Fifth International Basil Bernstein Symposium, July 9-12, in Cardiff University, Cardiff.

Maton,K. (2009). Cumulative and segmented learning: Exploring the role of curriculum structures in knowledge-building. British Journal of Sociology of Education, 30(1), 43-57. http://dx.doi.org/10.1080/01425690802514342

Mifflin. (1995). Management and organization, South -Western Publishers, New York, USA.

Reay, D. (2004). 'It's all becoming a habitus': Beyond the habitual use of habitus in educational research. British Journal of Sociology of Education, 25(4), 431-440. http://dx.doi.org/10.1080/0142569042000236934 


\section{Macrothink}

Journal of Studies in Education

ISSN 2162-6952 2013, Vol. 3, No. 2

Reay, D., G. Crozier, \& J. Clayton. (2009). Strangers in paradise: Working class students in elite universities. Sociology, 43(6), 1103-1121. http://dx.doi.org/10.1177/0038038509345700

Ricks, B.R., M.L Glinn, \& A.S. Daughtrey. (1995). Contemporary supervision, Managing people and Technology. Mc-Graw Hill In, NY, USA.

Rolstad, K., Mahoney, K., \& Glass, G. (2005). The big picture: A meta-analysis of program effectiveness research on English language learners. Educational Policy, 19, 572-594. http://dx.doi.org/10.1177/0895904805278067

Rossell, C. (2002). Dismantling bilingual education implementing English immersion: The California initiative. San Francisco, CA: Public Policy Institute of California.

Rossell, C., \& Baker, K. (1996). The educational effectiveness of bilingual education. Research in the Teaching of English, 30, 7-69.

Rowland, S. (2008) .Collegiality and intellectual love. British Journal of Sociology of Education, 29(3), 353-360. http://dx.doi.org/10.1080/01425690801966493

Rowland, S. (2009). Kindness. London Review of Education, 7(3), 207-210. http://dx.doi.org/10.1080/14748460903290272

Schunk, Silver D.H (2002). Motivation in Education, theory, Research and applications, 2nd edition. N.J Merril / Prentice Hall.USA.

Tarter, C.J. (2004). Lecture presented at St. John's University, Oakdale, New York: September $10,2004$. 